\title{
PART and SNAP
}

\author{
Clifford R. Jack Jr.
}

Received: 28 October 2014 / Accepted: 28 October 2014 / Published online: 8 November 2014

(C) The Author(s) 2014. This article is published with open access at Springerlink.com

The condition described by Crary et al. [5] of predominantly medial temporal lobe tauopathy in the absence of $\beta$-amyloidosis has a clear parallel in the recent imaging/ biomarker literature. Individuals with imaging/biomarker evidence of Alzheimer's disease (AD)-like neurodegeneration without $\beta$-amyloidosis have been labeled "suspected non-Alzheimer's pathophysiology (SNAP)" [8, 13, 18, 22, 27, 30, 31, 34, 37, 39, 41, 44].

Biomarkers of $\beta$-amyloidosis are amyloid PET and low CSF A 342 . Biomarkers of AD-related neurodegeneration are high CSF tau (total or phosphorylated); atrophy on structural MRI in an AD-like topographic pattern (particularly medial temporal structures); and decreased metabolism on FDG-PET in an AD-like topographic pattern [14]. Positive or negative cut points for each biomarker modality have typically been established in relation to $\mathrm{AD}$ dementia subjects $[8,13,18,22,27,30,31,34,37,39,41$, 44]. By designating subjects as either $\beta$-amyloid positive or negative, and neurodegeneration positive or negative, every individual can be classified into one of four groups: neither amyloidosis nor neurodegeneration; amyloidosis without neurodegeneration; amyloidosis plus neurodegeneration; or, neurodegeneration without amyloidosis (i.e., SNAP). We [18] originally labeled this last group SNAP because we felt that neurodegeneration in this group represented non-AD etiologies; however, as discussed later in this commentary, the designation "non-AD" has been controversial. While the SNAP construct was initially described in cognitively normal elderly [18] it has also been applied to categorize mildly impaired individuals.

C. R. Jack Jr. $(\bowtie)$

Department of Radiology, Mayo Clinic and Foundation, 200 First Street SW, Rochester, MN 55905, USA

e-mail: jack.clifford@mayo.edu

\section{Linking neurodegeneration in SNAP to PART pathology}

The link between atrophy of medial temporal structures on MRI and the pathology of PART is straightforward, as is the link between abnormally elevated CSF tau and the pathology of PART. The link between decreased metabolism in AD-like areas on FDG-PET and the pathology of PART may, however, not be intuitively obvious. Medial parietal and lateral temporal/parietal cortical hypometabolism in PART could be explained by direct involvement of these areas by tauopathy which has extended beyond the medial temporal lobe as described in Crary et al. [5]. It could also be explained, however, by the fact that the medial temporal lobe (always involved in PART) is highly connected functionally to the posterior default mode network which is located anatomically in medial parietal and lateral temporal/parietal cortex and therefore overlaps extensively with the AD-like hypometabolism pattern $[1,2,36]$.

\section{Parallels between PART and SNAP}

At least 12 different studies in seven different cohorts have been published to date describing characteristics of SNAP in cognitively normal elderly subjects $[13,18,20-23,27$, $34,37,39,41,44]$. And at least three studies in four different cohorts have been published describing SNAP in MCI subjects [8, 30, 31]. Clear parallels exist between SNAP and PART in several areas.

First, while population frequencies of PART are not estimated in Crary et al. [5], PART is judged to be common in middle-aged and elderly subjects. SNAP is likewise common in subjects over age 65 . Of 1,425 cognitively normal subjects reported from seven different centers, $315(22 \%)$ 
were categorized as SNAP [18, 22, 27, 37, 39, 41]. Of 277 MCI subjects reported from 4 different studies, 68 (25\%) were categorized as SNAP [8, 30, 31]. Given the large numbers of subjects included in these studies (esp. cognitively normal) the population frequency estimates of SNAP are likely reliable.

Second, APOE4 is underrepresented in both PART and SNAP. The frequency of APOE4 carriership among subjects with definite PART ranges from 9.1 to $20 \%$ for different Braak stages (Table 1, in Crary et al. [5]). Among cognitively normal SNAP subjects, reported frequencies of APOE4 carriership ranged from 12 to $30 \%$ [18, 22, 27, 41]. In all these studies, the frequency of APOE4 in SNAP was dramatically lower than in subjects with preclinical AD.

Third, the cognitive/clinical profile of both SNAP and PART is one of no impairment to mild cognitive impairment. Frank dementia appears to be rare in SNAP [24]. Mean MMSE scores among subjects with definite PART grouped by Braak stage (with average age in the $80 \mathrm{~s}$ ) ranged from 28 to 24 Table 1 in Crary et al. [5]). SNAP in turn has been described in subjects who are either cognitively normal or MCI. Furthermore, longitudinal clinical follow-up of cognitively normal SNAP subjects reveals a somewhat benign trajectory where the risk of clinical/cognitive decline for SNAP is significantly less than subjects classified as both amyloidosis and neurodegeneration positive [22, 27, 34, 39, 41].

\section{Caveats concerning parallels between PART and SNAP}

Drawing parallels between SNAP and PART comes with an important caveat-neurodegenerative imaging/biomarker non-specificity. The imaging findings used to define neurodegeneration in SNAP are not specific for temporal lobe tauopathy (i.e., PART). While hippocampal/medial temporal atrophy on MRI correlates well with tau burden and Braak stage [15, 43], other pathologies also produce hippocampal atrophy. These are well known to pathologists and include hippocampal sclerosis [15, 29, 33, 45], frontotemporal lobar degeneration (especially with TDP43 pathology [42]), argyrophilic grain disease, and ischemia/ anoxia [7]. Temporal/parietal FDG-PET hypometabolism also occurs in conditions other than temporal lobe tauopathy, for example, cerebrovascular disease [44]. The same caveat applies to elevated CSF tau, which is seen in conditions other than PART including ischemic cerebrovascular disease, traumatic brain injury, and Creutzfeldt-Jakob disease [38].

These caveats notwithstanding, to date, autopsy results have been reported in 4 SNAP subjects [41]. Three of the four had low probability $\mathrm{AD}$ and the fourth was not $\mathrm{AD}$ by NIA-AA pathological criteria $[12,26]$. Two of the four autopsy reports [41] described medial temporal tauopathy without amyloidosis-i.e., they met the definition of PART.

A solution for imaging/biomarker non-specificity may soon be at hand. Tau PET ligands have recently been developed $[4,25,40]$ and the hope (or expectation) is that tau PET will reveal the contribution of tau to the neurodegenerative profile seen in subjects labeled SNAP on the basis of MRI, FDG-PET and CSF tau.

\section{The chief controversy: is PART a non-AD process or part of the AD spectrum?}

As asserted in the accompanying commentary, the major controversy with PART is whether it should be considered an age-related non-AD entity or part of the AD pathological spectrum. Precisely, the same controversy exists in the imaging/biomarker literature on SNAP. Some in the imaging/biomarker community argue that evidence of $\beta$-amyloid deposition is required to label an individual as being in the "AD pathophysiological pathway" on the basis of biomarkers and hence SNAP is correctly labeled a non$\mathrm{AD}$ condition. Others argue that because the neurodegenerative biomarkers in SNAP are AD-like, SNAP represents a "pre fibrillar amyloid" part of the AD spectrum [3]. Elegant arguments have appeared on both sides of this debate.

There may be a way, however, to reconcile these opposing viewpoints on both PART and SNAP. A series of recent publications in the imaging/biomarker literature have proposed the following step-wise scenario as a common pathological and biomarker sequence in late-onset $\mathrm{AD}[16,17$, $19,28]$. This proposed pathological sequence is in fact based on earlier autopsy literature $[6,9,32]$.

1. Essentially everyone in the population develops PART at some point in life. Typically this occurs prior to significant fibrillar amyloid deposition. By itself, however, PART produces none to mild clinical symptomatology.

2 . Independently from PART, $\beta$-amyloidosis develops in neocortical areas $[10,35]$.

3. At some point in time, which varies considerably from person to person and through as yet undetermined signaling mechanisms, $\beta$-amyloidosis begins to induce the spread of tauopathy from medial temporal to widespread neocortical association areas.

4. Severe clinical symptoms are due to direct involvement of neocortical areas by the accelerated and expanding tauopathy, not due to direct involvement by $\beta$-amyloid deposition.

In this model of late-onset $\mathrm{AD}[6,9,16,17,19,28$, $32]$, the role of $\beta$-amyloid is to induce the propagation of tauopathy, rather than to initiate the first tau deposition in 
the brain (as is likely the case in genetically determined $\mathrm{AD}$ [11]).

In summary, the paper by Crary et al. [5] formalizes a key concept that links autopsy findings to imaging/biomarker findings and fills a void that the imaging/biomarker community has struggled with for several years. By introducing the term PART and characterizing this entity Crary et al. [5] have provided the clinical, imaging/biomarker community with an important foundation on which to rest future studies.

Acknowledgements This study was funded by National Institute on Aging (RO1-AG011378, RO1-AG041851); the Alexander Family Professorship of Alzheimer's Disease Research.

Conflict of interest Dr. Jack has provided consulting services for Janssen Research and Development, LLC. He received research funding from the NIH [R01-AG011378, U01-HL096917, U01-AG024904, RO1 AG041851, R01 AG37551, R01AG043392, U01-AG06786], and the Alexander Family Alzheimer's Disease Research Professorship of the Mayo Foundation.

Open Access This article is distributed under the terms of the Creative Commons Attribution License which permits any use, distribution, and reproduction in any medium, provided the original author(s) and the source are credited.

\section{References}

1. Buckner RL, Sepulcre J, Talukdar T, Krienen FM, Liu H, Hedden T, Andrews-Hanna JR, Sperling RA, Johnson KA (2009) Cortical hubs revealed by intrinsic functional connectivity: mapping, assessment of stability, and relation to Alzheimer's disease. J Neurosci 29(6):1860-1873

2. Buckner RL, Snyder AZ, Shannon BJ, LaRossa G, Sachs R, Fotenos AF, Sheline YI, Klunk WE, Mathis CA, Morris JC, Mintun MA (2005) Molecular, structural, and functional characterization of Alzheimer's disease: evidence for a relationship between default activity, amyloid, and memory. J Neurosci 25(34):7709-7717

3. Chetelat G (2013) Alzheimer disease: abeta-independent processes-rethinking preclinical AD. Nat Rev Neurol 9(3):123-124. doi:10.1038/nrneurol.2013.21

4. Chien DT, Bahri S, Szardenings AK, Walsh JC, Mu F, Su MY, Shankle WR, Elizarov A, Kolb HC (2013) Early clinical PET imaging results with the novel PHF-tau radioligand [F-18]-T807. J Alzheimers Dis 34(2):457-468. doi:10.3233/JAD-122059

5. Crary JF, Trojanowski JQ, Schneider JA, Abisambra JF, Abner EL, Alafuzoff I, Arnold SE, Attems J, Beach TG, Bigio EH, Cairns NJ, Dickson DW, Gearing M, Grinberg LT, Hof PR, Hyman BT, Jicha GA, Jellinger KA, Kovacs GG, Knopman D, Kofler J, Kukull WA, Mackenzie IR, Masliah E, McKee AC, Montine TJ, Murray ME, Neltner JH, Santa-Maria I, Seeley WW, Serrano-Pozo A, Shelanski ML, Stein TD, Takao M, Thal DR, Toledo JB, Troncoso JC, Vonsattel JP, White CL, 3rd, Wisniewski T, Woltjer RL, Yamada M, Nelson PT (2014) Primary age-related tauopathy (PART): a common pathology associated with human aging. Acta Neuropathol. doi:10.1007/s00401-014-1349-0

6. Delacourte A, Sergeant N, Wattez A, Maurage CA, Lebert F, Pasquier F, David JP (2002) Tau aggregation in the hippocampal formation: an ageing or a pathological process? Exp Gerontol 37(10-11):1291-1296

7. Di Paola M, Caltagirone C, Fadda L, Sabatini U, Serra L, Carlesimo GA (2008) Hippocampal atrophy is the critical brain change in patients with hypoxic amnesia. Hippocampus 18(7):719-728. doi:10.1002/hipo.20432

8. Duara R, Loewenstein DA, Shen Q, Barker W, Potter E, Varon D, Heurlin K, Vandenberghe R, Buckley C (2013) Amyloid positron emission tomography with (18)F-flutemetamol and structural magnetic resonance imaging in the classification of mild cognitive impairment and Alzheimer's disease. Alzheimers Dement 9(3):295-301. doi:10.1016/j.jalz.2012.01.006

9. Duyckaerts C, Hauw JJ (1997) Prevalence, incidence and duration of Braak's stages in the general population: can we know? Neurobiol Aging 18(4):362-369 (discussion 389-392)

10. Duyckaerts C, Uchihara T, Seilhean D, He Y, Hauw JJ (1997) Dissociation of Alzheimer type pathology in a disconnected piece of cortex. Acta Neuropathol 93(5):501-507

11. Hardy J, Selkoe DJ (2002) The amyloid hypothesis of Alzheimer's disease: progress and problems on the road to therapeutics. Science 297(5580):353-356

12. Hyman BT, Phelps CH, Beach TG, Bigio EH, Cairns NJ, Carrillo MC, Dickson DW, Duyckaerts C, Frosch MP, Masliah E, Mirra SS, Nelson PT, Schneider JA, Thal DR, Thies B, Trojanowski JQ, Vinters HV, Montine TJ (2012) National Institute on aging-Alzheimer's Association guidelines for the neuropathologic assessment of Alzheimer's disease. Alzheimers Dement 8(1):1-13. doi:10.1016/j.jalz.2011.10.007

13. Ivanoiu A, Dricot L, Gilis N, Grandin C, Lhommel R, Quenon L, Hanseeuw B (2014) Classification of non-demented patients attending a memory clinic using the new diagnostic criteria for Alzheimer's disease with disease-related biomarkers. J Alzheimers Dis. doi:10.3233/JAD-140651

14. Jack CR Jr, Albert MS, Knopman DS, McKhann GM, Sperling RA, Carillo M, Thies W, Phelps CH (2011) Introduction to the recommendations from the National Institute on Aging-Alzheimer's Association workgroups on diagnostic guidelines for Alzheimer's disease. Alzheimers Dement 7(3):257-262

15. Jack CR Jr, Dickson DW, Parisi JE, Xu YC, Cha RH, O'Brien PC, Edland SD, Smith GE, Boeve BF, Tangalos EG, Kokmen E, Petersen RC (2002) Antemortem MRI findings correlate with hippocampal neuropathology in typical aging and dementia. Neurology 58(5):750-757

16. Jack CR Jr, Holtzman DM (2013) Biomarker modeling of Alzheimer's Disease. Neuron 80(6):1347-1358

17. Jack CR Jr, Knopman DS, Jagust WJ, Petersen RC, Weiner MW, Aisen PS, Shaw LM, Vemuri P, Wiste HJ, Weigand SD, Lesnick T, Pankratz VS, Donohue M, Trojanowski JQ (2013) Tracking pathophysiological processes in Alzheimer's disease: an updated hypothetical model of dynamic biomarkers. Lancet Neurol 12(2):207-216. doi:10.1016/S1474-4422(12)70291-0

18. Jack CR Jr, Knopman DS, Weigand SD, Wiste HJ, Vemuri P, Lowe V, Kantarci K, Gunter JL, Senjem ML, Ivnik RJ, Roberts R, Rocca WA, Boeve BF, Petersen RC (2012) An operational approach to NIA-AA criteria for preclinical Alzheimer's disease. Ann Neurol 71(6):765-775

19. Jack CR Jr, Wiste HJ, Knopman DS, Vemuri P, Mielke MM, Weigand SD, Senjem ML, Gunter JL, Lowe V, Gregg BE, Pankratz VS, Petersen RC (2014) Rates of beta-amyloid accumulation are independent of hippocampal neurodegeneration. Neurology 82(18):1605-1612. doi:10.1212/WNL.0000000000000386

20. Jack CR Jr, Wiste HJ, Weigand SD, Knopman DS, Lowe V, Vemuri P, Mielke MM, Jones DT, Senjem ML, Gunter JL, Gregg BE, Pankratz VS, Petersen RC (2013) Amyloid-first and neurodegeneration-first profiles characterize incident amyloid 
PET positivity. Neurology 81(20):1732-1740. doi:10.1212/01. wnl.0000435556.21319.e4

21. Jack CR Jr, Wiste HJ, Weigand SD, Rocca WA, Knopman DS, Mielke MM, Lowe VJ, Senjem ML, Gunter JL, Preboske GM, Pankratz VS, Vemuri P, Petersen RC (2014) Age-specific population frequencies of cerebral beta-amyloidosis and neurodegeneration among people with normal cognitive function aged 50-89 years: a cross-sectional study. Lancet Neurol 13(10):9971005. doi:10.1016/S1474-4422(14)70194-2

22. Knopman DS, Jack CR Jr, Wiste HJ, Weigand SD, Vemuri P, Lowe V, Kantarci K, Gunter JL, Senjem ML, Ivnik RJ, Roberts RO, Boeve BF, Petersen RC (2012) Short-term clinical outcomes for stages of NIA-AA preclinical Alzheimer disease. Neurology 78(20):1576-1582. doi:10.1212/WNL.0b013e3182563bbe

23. Knopman DS, Jack CR Jr, Wiste HJ, Weigand SD, Vemuri P, Lowe VJ, Kantarci K, Gunter JL, Senjem ML, Mielke MM, Roberts RO, Boeve BF, Petersen RC (2013) Brain injury biomarkers are not dependent on beta-amyloid in normal elderly. Ann Neurol 73(4):472-480. doi:10.1002/ana.23816

24. Lowe VJ, Peller PJ, Weigand SD, Montoya Quintero C, Tosakulwong N, Vemuri P, Senjem ML, Jordan L, Jack CR Jr, Knopman D, Petersen RC (2013) Application of the National Institute on Aging-Alzheimer's Association AD criteria to ADNI. Neurology 80(23):2130-2137. doi:10.1212/WNL.0b013e318295d6cf

25. Maruyama M, Shimada H, Suhara T, Shinotoh H, Ji B, Maeda J, Zhang MR, Trojanowski JQ, Lee VM, Ono M, Masamoto K, Takano H, Sahara N, Iwata N, Okamura N, Furumoto S, Kudo Y, Chang Q, Saido TC, Takashima A, Lewis J, Jang MK, Aoki I, Ito H, Higuchi M (2013) Imaging of tau pathology in a tauopathy mouse model and in Alzheimer patients compared to normal controls. Neuron 79(6):1094-1108. doi:10.1016/j. neuron.2013.07.037

26. Montine TJ, Phelps CH, Beach TG, Bigio EH, Cairns NJ, Dickson DW, Duyckaerts C, Frosch MP, Masliah E, Mirra SS, Nelson PT, Schneider JA, Thal DR, Trojanowski JQ, Vinters HV, Hyman BT (2012) National Institute on Aging-Alzheimer's Association guidelines for the neuropathologic assessment of Alzheimer's disease: a practical approach. Acta Neuropathol 123(1):1-11. doi:10.1007/s00401-011-0910-3

27. Mormino EC, Betensky RA, Hedden T, Schultz AP, Amariglio RE, Rentz DM, Johnson KA, Sperling RA (2014) Synergistic effect of beta-amyloid and neurodegeneration on cognitive decline in clinically normal individuals. JAMA Neurol. doi:10.1 001/jamaneurol.2014.2031

28. Musiek ES, Holtzman DM (2012) Origins of Alzheimer's disease: reconciling cerebrospinal fluid biomarker and neuropathology data regarding the temporal sequence of amyloid-beta and tau involvement. Curr Opin Neurol 25(6):715-720. doi:10.1097 /WCO.0b013e32835a30f4

29. Nelson PT, Smith CD, Abner EL, Wilfred BJ, Wang WX, Neltner JH, Baker M, Fardo DW, Kryscio RJ, Scheff SW, Jicha GA, Jellinger KA, Van Eldik LJ, Schmitt FA (2013) Hippocampal sclerosis of aging, a prevalent and high-morbidity brain disease. Acta Neuropathol 126(2):161-177. doi:10.1007/s00401-013-1154-1

30. Petersen RC, Aisen P, Boeve BF, Geda YE, Ivnik RJ, Knopman DS, Mielke M, Pankratz VS, Roberts R, Rocca WA, Weigand S, Weiner M, Wiste H, Jack CR Jr (2013) Criteria for mild cognitive impairment due to Alzheimer's disease in the community. Ann Neurol. doi:10.1002/ana.23931

31. Prestia A, Caroli A, van der Flier WM, Ossenkoppele R, Van Berckel B, Barkhof F, Teunissen CE, Wall AE, Carter SF, Scholl M, Choo IH, Nordberg A, Scheltens P, Frisoni GB (2013) Prediction of dementia in MCI patients based on core diagnostic markers for Alzheimer disease. Neurology 80(11):1048-1056. doi:10.1212/ WNL.0b013e3182872830
32. Price JL, Morris JC (1999) Tangles and plaques in nondemented aging and "preclinical" Alzheimer's disease. Ann Neurol 45(3):358-368

33. Probst A, Taylor KI, Tolnay M (2007) Hippocampal sclerosis dementia: a reappraisal. Acta Neuropathol 114(4):335-345. doi:10.1007/s00401-007-0262-1

34. Roe CM, Fagan AM, Grant EA, Hassenstab J, Moulder KL, Maue Dreyfus D, Sutphen CL, Benzinger TL, Mintun MA, Holtzman DM, Morris JC (2013) Amyloid imaging and CSF biomarkers in predicting cognitive impairment up to 7.5 years later. Neurology 80(19):1784-1791. doi:10.1212/WNL.0b013e3182918ca6

35. Small SA, Duff K (2008) Linking Abeta and tau in late-onset Alzheimer's disease: a dual pathway hypothesis. Neuron 60(4):534542. doi:10.1016/j.neuron.2008.11.007

36. Sperling RA, Laviolette PS, O'Keefe K, O'Brien J, Rentz DM, Pihlajamaki M, Marshall G, Hyman BT, Selkoe DJ, Hedden T, Buckner RL, Becker JA, Johnson KA (2009) Amyloid deposition is associated with impaired default network function in older persons without dementia. Neuron 63(2):178-188

37. Toledo JB, Weiner MW, Wolk DA, Da X, Chen K, Arnold SE, Jagust W, Jack C, Reiman EM, Davatzikos C, Shaw LM, Trojanowski JQ (2014) Neuronal injury biomarkers and prognosis in ADNI subjects with normal cognition. Acta Neuropathol Commun 2(1):26. doi:10.1186/2051-5960-2-26

38. Tsitsopoulos PP, Marklund N (2013) Amyloid-beta peptides and tau protein as biomarkers in cerebrospinal and interstitial fluid following traumatic brain injury: a review of experimental and clinical studies. Front Neurol 4:79. doi:10.3389/fneur.2013.00079

39. van Harten AC, Smits LL, Teunissen CE, Visser PJ, Koene T, Blankenstein MA, Scheltens P, van der Flier WM (2013) Preclinical $\mathrm{AD}$ predicts decline in memory and executive functions in subjective complaints. Neurology 81(16):1409-1416. doi:10.121 2/WNL.0b013e3182a8418b

40. Villemagne VL, Furumoto S, Fodero-Tavoletti MT, Mulligan RS, Hodges J, Harada R, Yates P, Piguet O, Pejoska S, Dore V, Yanai K, Masters CL, Kudo Y, Rowe CC, Okamura N (2014) In vivo evaluation of a novel tau imaging tracer for Alzheimer's disease. Eur J Nucl Med Mol Imaging 41(5):816-826. doi:10.1007/ s00259-013-2681-7

41. Vos SJ, Xiong C, Visser PJ, Jasielec MS, Hassenstab J, Grant EA, Cairns NJ, Morris JC, Holtzman DM, Fagan AM (2013) Preclinical Alzheimer's disease and its outcome: a longitudinal cohort study. Lancet Neurol 12(10):957-965. doi:10.1016/ S1474-4422(13)70194-7

42. Whitwell JL, Jack CR Jr, Parisi JE, Senjem ML, Knopman DS, Boeve BF, Rademakers R, Baker M, Petersen RC, Dickson DW, Josephs KA (2010) Does TDP-43 type confer a distinct pattern of atrophy in frontotemporal lobar degeneration? Neurology 75(24):2212-2220. doi:10.1212/WNL.0b013e31820203c2

43. Whitwell JL, Josephs KA, Murray ME, Kantarci K, Przybelski SA, Weigand SD, Vemuri P, Senjem ML, Parisi JE, Knopman DS, Boeve BF, Petersen RC, Dickson DW, Jack CR Jr (2008) MRI correlates of neurofibrillary tangle pathology at autopsy: a voxel-based morphometry study. Neurology 71(10):743-749

44. Wirth M, Villeneuve S, Haase CM, Madison CM, Oh H, Landau SM, Rabinovici GD, Jagust WJ (2013) Associations between Alzheimer disease biomarkers, neurodegeneration, and cognition in cognitively normal older people. JAMA Neurol. doi:10.1001/ja maneurol.2013.4013

45. Zarow C, Vinters HV, Ellis WG, Weiner MW, Mungas D, White L, Chui HC (2005) Correlates of hippocampal neuron number in Alzheimer's disease and ischemic vascular dementia. Ann Neurol 57(6):896-903 